\title{
Amanita magnivolvata sp. nova (Agaricales)
}

\author{
Marjatta Aalto \\ Department of Botany, University of Helsinki, Unioninkatu 44, SF-00170 Helsinki 17, Finland \\ Aalto, Marjatta 1974: Amanita magnivolvata sp. nova (Agaricales) \\ - Karstenia: 89-92. A new species, Amanita (sec. Vaginatae) magnivolvata Aalto, is \\ described from southwestern Finland.
}

Late in autum 1972 an unknown species of Amanita, with a very distinctive appearance, was found by me in the commune of Karjalohja, southwestern Finland. The most conspicuous feature of the fruit bodies (Fig. 1), besides their robust habitus, was the large, thick, ample, saccate volva. The colour of the cap when fresh was grey with an olive tinge; the stipe was stout, solid, without an annulus; the spores are broadly ellipsoid. The taxonomy of the genus Amanita is somewhat difficult, partly because many taxa, especially in the section Vaginatae, have not yet been properly described and delimited. However, in view of the distinctive appearance of this find, I assumed that if it had already been described, it would be easily identified. A search through the literature showed that it might be Amanita argentea Huijsman, or some closely related taxon. However, it differs from that species in such features as the colour of the cap and aspect of the volva.

Habitus robustus. Annulus deest. Volva magna, glabra, alba, ad tactum passim maculas ferrugineas creans, in lobos 2-3 fissa, duabus plicis prominentibus rotundatis ad basin volvae utrimque sitis; hyphae longae, angustae, (4-10 $\mu$ ), intertextae dominantes, fibulae non visae. Pileus carnosus, crassus, 80-115 $\mathrm{mm}$ latus, margine sulcatus (15 $\mathrm{mm})$; pellis ex olivaceo grisea, sicca, nitida, in exiccato alutacea; superficies pilei sine fragmentis volvae. Lamellae liberae, crassae, cremeae, textura marginali sterili prominenti, flocculosa, cellulis pyriformibus, 10-60 $x$ 15-30 $\mu$. Stipe validus, 95-125 $\times 15$ $20 \mathrm{~mm}$, solidus, farcatus, superficie hyphis subviscidis tomentosa; sub pileo leviter striatus. Differt ab aliis speciebus sporis ellipsoideis, inamyloideis, annulo deficienti, volva magna, crassa, saccata, ab A. argentea Huijsman colore pilei, ab A. lividopallescenti Gillet margine longius sulcato, sporis latioribus.

Holotypus: Finland. Varsinais-Suomi. Karjalohja: Puujärvi, Herniemi, grass-herb forest, 1. X. 1972 M. Aalto $1600(\mathrm{H})$.

Pileus fleshy, thick, $80-115 \mathrm{~mm}$ broad, dome-shaped in young fruit bodies (completely adult fruit bodies not seen by me). Pellis grey-coloured with a slight olive tinge. A faint, deeper grey ring distinguishable behind 15-mm-broad, sulcate margin. (Fig. 1a). When dried, the colour turning to leather brown. Surface dry, glossy, without volval remnants.

Lamellae free, thick, 3-4 $\mathrm{mm}$ broad, cream coloured or whiiish, their edges with conspicuous, white, flocculose marginal tissue (Fig. 4a), cells of which pyriform, 10$60 \times 15-30 \mu$, the large ones dominating.

Spores white, inamyloid, broadly ellipsoid 


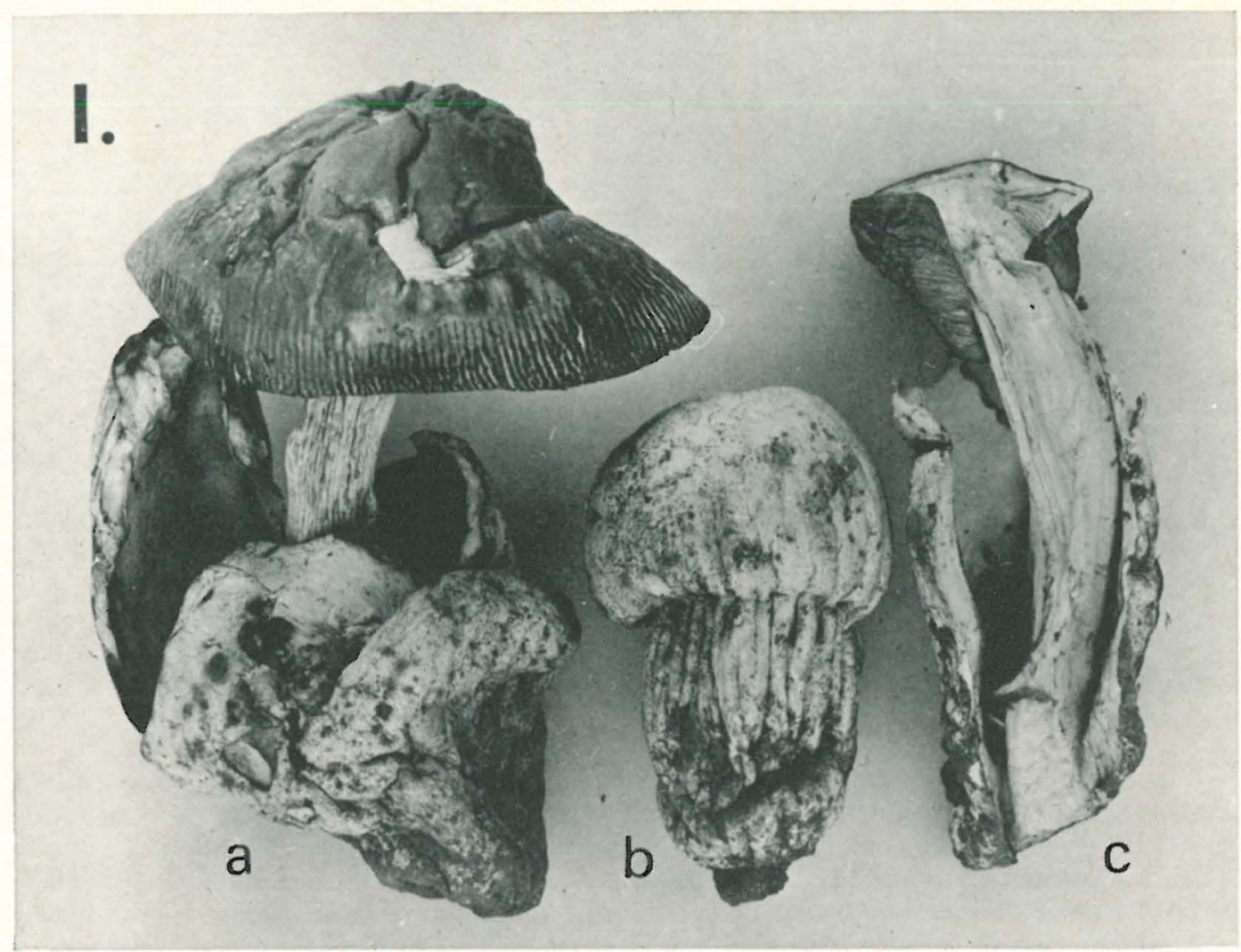

Fig. 1 a-c: Dried specimens of Amanita magnivolvata. Holatype. Natural size (1:1) Photo Mauri Korhonen

a. An older fruit body.

b. Young fruit body, enclosed in volva.

c. Young fruit body, longitudinal section.

(Fig. 2), 10.0-12.1-14.5 x 8.0-10.1-11.5 $\mu$ (mean length/breadth ratio 1.2) Similar values are reported for $A$. argentea (HuijsMAN 1959, BAS 1967). The form and size of the spores distinguish these species from $A$. vaginata (Bull. ex Fr.) Vitt. and related grey-caped taxa with which they might be confused ( $A$. vaginata has smaller globose spores, and a more fragile habitus owing to the longer, slender stipe, thinner pileus). Basidia clavate, $50-75 \times 20-25 \mu$, tetrasporous but some observed to be bisporous (Fig. 4b).

Stipe stout, 95-125 mm long, 15-20 mm in diameter, colour whitish, surface uneven owing to tomentose, slightly viscid hyphae. Just below pileus stipe finely striated (like prints of gills) with down-like hyphae. Stipe solid, stuffed, medulla collapsed when dry with transverse stripes (Fig. 1c). Annulus lacking.

Volva large, about $60 \mathrm{~mm}$ high, $5-10 \mathrm{~mm}$ thick, ample, saccate, felty, smooth both inside and outside; colour in fresh specimens pure white. When handled, its surface developed small, rusty yellow spots, which persisted when the specimens were dried. One of the three fruit bodies (Fig. 1b) is still enclosed in the thick volva: the form of the fresh volva was obovoid, with no constriction to mark the joint between the pileus and the stipe. The volva is coherent, composed mainly of narrow $(4-10 \mu)$, long, interwoven hyphae (Fig. 3a-c). It is spit into $2-3$ lobes $4-5 \mathrm{~cm}$ above the base, but does not break up and form patches on cap surface as is usual in A. lividopallescens Gillet. Clamps not seen.

A positive colour reaction was obtained in the flesh of a dry specimen $1-2$ min after treatment with a $2 \%$ phenol solution. The reaction begins with a faint violet tone, which darkens to wine red-brown. 
One peculiar feature, associated with the volva, should be mentioned. All three fruit bodies have a remarkable, rounded fold on either side of volva base (Fig. 1a,b). This feature was very distinct in fresh specimens. However, BAS (1969: 310-311) states that the form and size of volva of a species can be influenced by environmental factors, such as the degree of humidity and the mechanical resistance offered by the soil.
$A$. argentea differs from $A$. magnivolvata in the silver-grey colour of the cap (HuijsMAN 1959:14 describes it as »beau gris argenté ou gris cendré»; BAs 1967: 126 as »schön gleichmässig hell silbergrau, diese Farbe beim Trocknen bewahrend»). Dr. C. Bas (Leiden), who as the specialist of the genus Amanita, has kindly given his opinion on the present collection, also reports (in litt.) that the volva of $A$. argentea is usually thin and
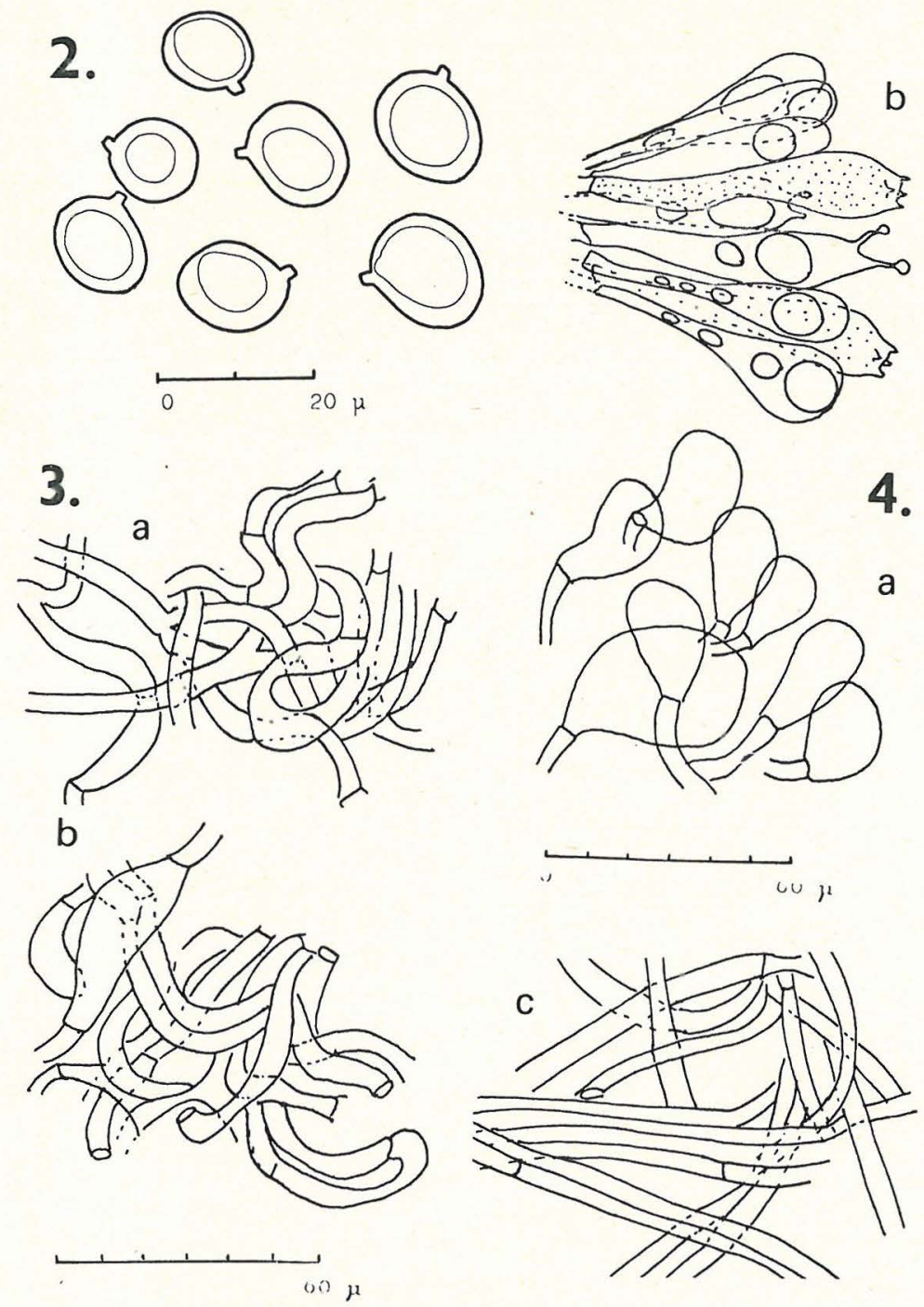

Fig. 2: Seven spores of Amanita magnivolvata.

Fig. 3 a-c: Volval elements in different sections.

a. Hyphae in longitudinal section, middle part of volva.

b. Hyphae in cross-section, middle part of volva.

c. Hyphae in tangetial section of outer layers of volva.

Fig. 4 a-b: Lamellar tissues.

a. Sterile marginal tissue of lamella.

b. Hymenium in cross-section of lamella. 
appressed against the base of the stem; there are also differences in the habitus of these species. He could not decide to which species the present collection belongs, and suggested that it would be better to describe it under a new name. He considers that it is »probably not far from A. lividopallescens sensu Gillet». However, A. magnivolvata differs from that species in the large, smoot volva that does not break up, the colour of the cap (no brown or ochre tone fresh), the longer sulcation of the margin and the broader ellipsoid spores. Kallio (1963: 49) has published a record of $A$. lividopallescens from South Finland, with a figure, but the habitus of the species, especially that of the volva, is also different from that of the present species.

It may be recalled that summer 1972 was exceptionally warm and sunny throughout nothern Europe, with unusually long, hot spells, lasting several weeks (cf. data of Ilmatieteellinen Laitos: 66, 1972: middle temperature of Juni was $1.0-2.0{ }^{\circ} \mathrm{C}$ July $2.5-3.0{ }^{\circ} \mathrm{C}$, August $1.0-1.5{ }^{\circ} \mathrm{C}$ higher than in the normal period years 1931-60; the rainfall being normal or higher). It will be remembered among mycologists as an exceptionally good mushroom year. A similar summer had not occurred in Finland since years 1937 - 39. This kind of summer may have induced a rare, seldom fruiting species, or a southern, perhaps thermophilous one to produce fruit bodies. This is the first time that I have found the species in this locality, which is situated behind my summer cottage, and has been carefully searched for mushrooms for many wears. In autum 1973, after another hot, but dry summer, it was not found there.

The specimens were collected in southwestern Finland, on 1 October. Three fruit bodies at different stages of development were growing $15-20 \mathrm{~cm}$ apart. The young individual (Fig. 1b), still completely enveloped by the volva, was almost wholly above the ground, only $1 / 4$ growing within the substrate. The habitat is deciduous grass-herb forest dominated by Corylus avellana, with Populus tremula, Betula pubescens and $B$. verrucosa, an a huge Picea abies in the immediate vicinity. The locality is near the edge of the forest and there is an abundant bush layer dominated by Rhamnus frangula, Salix spp, Alnus incana and Prunus padus. The substrate consists of a loose layer of leaf and twig litter underlain by clay. The herb layer was poorly developed owing to the deep shade.

The taxonomic position of Amanita magnivolvata is not quite clear. Singer (1960) places similar species with broad ellipsoid spores in a different section (sec. Ovigera Sing.) from $A$. vaginata and related taxa lacking an annulus. However, the significance of the presence or absence of an annulus in the classification of Amanita is not yet clear (cf. Huijsman 1959: 20). Otherwise the species could be placed near the $A$. caesarea group, which it resembles in external appearance.

\section{Acknowledgements.}

The author is indepted to professor Risto Tuomikoski for advice in taxonomic questions, to Dr. C. Bas (Leiden) for his kind comments on the specimens, to Dr. Harri Harmaja for comments on the manuscript, and to Mr. Mauri Korhonen, who photographed the specimens.

\section{REFERENCES}

BAs, C. 1967: Amanita argentea Huijsman am Teutoburger Wald gefunden. - Westfälische Pilzbrife 4 (7): $125-129$.

BAs, C. 1969: Morphology and subdivision of Amanita and a monograph of its section Lepidella. - Persoonia 5 (4): 285-279.

Huijsman, H. S. C. 1959: Deux Amanites mécounnes. - Bull. Soc. Mycol. France 75 (1): $14-32$.
Ilmatieteellinen Laitos, kuukausikatsaus Suomen ilmastoon 1972: Kesäkuu, heinäkuu, elokuu. - Vuosikerta 66. Helsinki.

Kallio, P. 1963: Zur Verbereitung einiger in Findand südlichen Pilze, besonderes in der südwestlichen Eichenzonen. - Karstenia 6-7: 35-76.

Singer, A. G. 1960: The Agaricales in modern taxonomy. 2nd ed. -- 915 pp. 75 pls. Weinheim. 